\title{
Uma viagem residual: os mortos, a travessia, o rio, o barco e o barqueiro na trilogia das Barcas
}

Francisco Wellington Rodrigues Lima1
http://lattes.cnpq.br/7287418515059707

Elizabeth Dias Martins ${ }^{2}$

http://lattes.cnpq.br/0811163781077772

Enviado em: 29/08/2018

Aceito em: 23/11/2018

RESUMO: $O$ presente artigo consiste em dissertar sobre a morte e o ato de morrer no teatro medieval português de Gil Vicente, na Trilogia das Barcas - do Inferno (1517), do Purgatório (1518) e da Glória (1519) -, abordando, em especial, quatro elementos significativos da morte: a morte como travessia, o barco, o barqueiro e o rio -, elementos importantes para a viagem dos mortos, símbolos de proteção e salvação. O nosso objetivo é demonstrar que há semelhanças e diferenças residuais na forma de ver, pensar e sentir a morte no teatro vicentino; semelhanças e diferenças oriundas de povos, culturas e tempos distantes, porquanto as culturas entram em contato umas com as outras, independentemente do tempo e do espaço, a todo momento, se atualizando e passando por modificações continuamente. Para tal, utilizamos os conceitos de resíduo, hibridismo, cristalização e mentalidade trabalhados pela Teoria da Residualidade Literária e Cultural sistematizada por Roberto Pontes. Para a orientação da nossa pesquisa investigativa, o método de procedimento utilizado será o comparativo. Buscaremos subsídios no corpus teórico da Literatura Comparada e os mesclaremos aos conceitos operativos da Teoria da Residualidade Cultural e Literária.

Palavras-chave: Gil Vicente; Trilogia das Barcas; Residualidade; Viagem dos Mortos.

ABSTRACT: The present article consists of a dissertation about the death and the act of dying in the Portuguese medieval theater of Gil Vicente, in the Trilogy of the Barges - Inferno (1517), Purgatório (1518) and Gloria (1519) in particular, four significant elements of death: death as a crossing, the boat, the boatman and the river - important elements for the journey of the dead, symbols of protection and salvation. Our objective is to demonstrate that there are similarities and residual differences in the way we see, think and feel death in the Vincentian theater; similarities and differences from peoples, cultures and distant times, because cultures come into contact with each other, regardless of time and space, at all times, updating and constantly changing. For that, we use the concepts of residue, hybridism, crystallization and mentality worked by the Theory of Literary and Cultural Residuality systematized by Roberto Pontes. For the orientation of our investigative research, the procedure method used will be the comparative one. We will seek subsidies in the theoretical corpus of Comparative Literature and mix them with the operative concepts of Theory of Cultural and Literary Residuality.

Keywords: Gil Vicente; Trilogy of the Barges; Residuality; Journey of the Dead.

\footnotetext{
${ }^{1}$ Doutor em Literatura Comparada pelo Programa de Pós-Graduação em Letras da Universidade Federal do Ceará (UFC). Docente da Universidade Aberta do Brasil (UAB/UFC).

E-mail:wellrodrigues2012@yahoo.com.br

2 Docente do Programa de Pós-Graduação em Letras: Literatura Comparada e do Departamento de Literatura da Universidade Federal do Ceará.

E-mail: bethdias@ufc.br
} 
A morte, segundo Ariès (1999), é o fim temporal da vida humana na terra. Nascemos, crescemos e vivemos a vida inteira em busca de coisas que podem nos fazer bem ou mal. No seu devido tempo, como um relógio que marca a hora exata, ela, a morte, chega. Tudo se finda. Dela ninguém escapa. Com ela, começa, para os cristãos e para quem acredita na vida eterna, um novo ciclo: o Além-túmulo.

Diante do mistério da morte e do Além, o homem, desde o início dos tempos, passou a se preocupar consigo, com o corpo e com a alma. Rituais foram desenvolvidos. A tradição ocidental em torno da morte ganhou grandes projeções em épocas diferenciadas do período clássico ao medievo e à contemporaneidade - ocupando assim, a mente do povo com imagens e significados diversos da vida e da morte de acordo com a religiosidade, o nível e o tipo de crença de cada um.

De acordo com o pensamento cristão medieval a morte tornou-se símbolo de passagem, de travessia, de viagem ao reino de Deus ou do Diabo. Era esperada e nunca, repentina. Tornou-se ainda símbolo de medo e de angústia diante do desconhecido, algo inevitável que levaria todos ao fim comum: a finitude do ser. A morte seria ainda o caminho para o Céu, o Inferno ou o Pu rgatório; caminho que levaria a alma humana ao encontro dos Anjos, Santos, Deus, Cristo, Virgem Maria ou do Diabo, demônios e dos pecados mundanais. De certa forma, esse modo de pensar a morte atravessou épocas e transformações culturais. Tornou-se, por exemplo, presente na corte portuguesa do século XVI, sendo representada, como veremos mais adiante, diversificada e repensada no teatro vicentino, de modo compatível com mentalidade cristã que se constituía na Idade Média, na Península Ibérica, híbrida por natureza.

Portanto, no decorrer deste trabalho investigativo, dissertaremos sobre a morte e o ato de morrer no teatro medieval português vicentino, na Trilogia das Barcas - do Inferno (1517), do Purgatório (1518) e da Glória (1519) -, abordando, em especial, quatro elementos significativos da morte: a morte como travessia, o barco, o barqueiro e o rio -, elementos importantes para a viagem dos mortos, símbolos de proteção e salvação. O nosso objetivo é demonstrar que há semelhanças e diferenças residuais na forma de ver, pensar e sentir a morte no teatro vicentino; semelhanças e diferenças oriundas de povos e tempos distantes; semelhanças e diferenças entre sociedades cujas culturas parecem nunca ter tido contato, uma vez que as culturas entram em contato umas com as outras, independentemente do tempo e do espaço, a todo momento, atualizando-se e se modificando continuamente. Para tal, utilizamos os conceitos de residuo, hibridismo, cristalização e mentalidade trabalhados pela Teoria da Residualidade sistematizada por Roberto Pontes ${ }^{3}$. Para a orientação da nossa

\footnotetext{
${ }^{3}$ Desde 2002 a Teoria da Residualidade é registrada junto à Pró-Reitoria de Pesquisa e de Pós-Graduação da Universidade Federal do Ceará e ao Conselho Nacional de Pesquisa - CNPq -, e sua propagação pelo universo da pesquisa ganha, a cada dia, mais notoriedade e espaço entre professores, pesquisadores e alunos de Programas de Pós-Graduação de IES do Brasil - a exemplo da UFC, UFAM, UEPB, UNIFAP, UVA, UNB, UFRR -, e do exterior - Universidade de Coimbra, Universidade de Trás-os Montes -, que reconhecem a importância da teoria no estudo da tradição cultural e literária. A Teoria da Residualidade já proporcionou seis teses concluídas de doutorado (quatro na UFC, duas na PUCRio e uma na UFAM); 39 dissertações de mestrado defendidas no PPGL-UFC/PPGL-UFAM; uma tese de doutorado defendida em Portugal, na Universidade de Trás-os Montes; uma tese de doutorado em andamento de defesa na Universidade de Coimbra; três teses em andamento no PPGL-UFC e uma na UNB; quatro dissertações em andamento também no PPGL-UFC. Oito Jornadas de Residualidade, eventos científicos nacionais, com participantes de universidades estrangeiras, já foram realizados pelo Grupo GERLIC na UFC, envolvendo, no seu formato, conferências, mesas-redondas, sessões de comunicações e apresentações culturais, tendo ainda, a participação de pesquisadores/conferencistas do Brasil e de Portugal. Dois livros foram publicados reunindo estudos com base na Teoria da Residualidade: 1. PONTES, Roberto; MARTINS, Elizabeth Dias (Organizadores). Residualidade ao Alcance de Todos. Fortaleza: Expressão Gráfica e Editora, 2015. 2. PONTES, Roberto; MARTINS, Elizabeth Dias; CERQUEIRA, Leonildo; NASCIMENTO, Cássia Maria Bezerra do (Organizadores). Residualidade e Intertemporalidade. Curitiba: CRV
} 
pesquisa investigativa, o método de procedimento utilizado será o comparativo. Buscaremos subsídios no corpus teórico da Literatura Comparada e os mesclaremos aos conceitos operativos da Teoria da Residualidade Literária e Cultural.

Roberto Pontes empregou o termo residualidade inicialmente em sua dissertação de mestrado, atualmente publicada em livro, cujo título é Poesia Insubmissa Afrobrasilusa (1999), tendo por objetivo demonstrar a presença de resquícios do passado que, ao longo do tempo, acumularam-se na mente humana e que são refletidos na cultura e na literatura de forma involuntária através de estruturas atualizadas.

Os termos resíduo, residual e residualidade, na concepção de Roberto Pontes, têm sido empregados relativamente ao que resta ou remanesce na Física, na Química, na Medicina, na Hidrografia, na Geologia e em outras ciências, mas na Literatura (história, teoria, critica e ensaística) quase não se tem feito uso dos mesmos (PONTES, 2006).

Segundo Roberto Pontes, resíduo é "aquilo que remanesce de uma época para outra e tem força de criar de novo toda uma obra, toda uma cultura” (PONTES, 2006). Bem sabemos que na cultura do povo do Nordeste do Brasil, por exemplo, é possível encontrar resquícios da época medieval muito vivos na mentalidade do homem nordestino, inclusive, daquilo que remanesceu acerca da Morte, do Julgamento e da Salvação, corpus central de nosso estudo, como bem representou Suassuna no Brasil de hoje, pois para Pontes, o resíduo "não é um cadáver da cultura grega ou da cultura medieval que deve ser reanimado nem venerado num culto obtuso de exaltação do antigo, do morto... não é isso... fica como material que tem vida" (PONTES, 2006).

Como podemos perceber, a teoria literária elaborada por Roberto Pontes parte do pressuposto de que "na cultura e na Literatura nada é original; tudo é remanescente; logo, tudo é residual". Assim sendo, entende-se por resíduo o compósito de sedimentos mentais que remanescem de uma cultura para outra. (PONTES, 2006). Tal fala, logo nos remete ao corpus da Teoria da Residualidade e seus conceitos operacionais: residualidade ${ }^{4}$, rristalização ${ }^{5}$, mentalidade 6 e hibridismo cultural. Sobre o assunto, Roberto Pontes afirma o seguinte:

Editora, 2017. Um terceiro livro está no prelo: PONTES, Roberto; MARTINS, Elizabeth Dias; NASCIMENTO, Mary; CRAVEIRO, William. Todas as idades são contemporâneas: Estudos de residualidade literária e cultural. Quatro livros autorais com base na Teoria da Residualidade: 1. PONTES, Roberto. O Jogo de Duplos na Poesia de Sá-Carneiro. Fortaleza: Edições UFC, 2012. Livro que conquistou o Prêmio Nacional de Literatura PEN Clube do Brasil 2014. 2. MARTINS, Elizabeth Dias. Do Fragmento à Unidade: a Lição de Gnose Almadiana. Fortaleza: Edições UFC, 2013. 3. MOREIRA, Rubenita Alves. Dos Mitos à Picaresca: uma caminhada residual pelo Auto da Compadecida. Saarbrücken, Alemanha: Editora Novas Edições Acadêmicas, 2016. 4. TORRES, José Willian Craveiro. Além da Cruz e da Espada: acerca dos resíduos clássicos d'a demanda do Santo Graal. Fortaleza: Imprensa Universitária, 2016. Atualmente, existem três grupos de pesquisa cadastrados no Diretório de Grupos de Pesquisas do CNPq, desenvolvendo estudos com base na Teoria da Residualidade, em plena atividade no Brasil: GERLIC - UFC; GERAM - UVA; LETRAR - UFAM. (LIMA, Tese de Doutorado, 2018). Dados atualizados até janeiro de 2019.

${ }^{4}$ Resíduo, Residual e Residualidade: refere-se a certas formações mentais que persistem através de longas durações. É dotado de extremo vigor e não se confunde com o arcaico. É aquilo que remanesce de uma época para outra e tem a força de criar de novo toda uma cultura ou obra literária; não é material morto e, sim, material que tem vida, porque continua a ser valorizado e vai infundir vida numa obra nova. (PONTES, 2006).

5 A cristalização é a sedimentação de resíduos culturais de outras épocas em obras contemporâneas. Trata-se de um modo coletivo de compreender a memória coletiva, uma vez que é sempre resultante de um processo de modificações contínuas das condições materiais. (PONTES, 2006).

${ }^{6}$ A mentalidade é um conjunto difuso de imagens a que se referem todos os membros de um mesmo grupo e está associada intrinsecamente ao resíduo. Trata-se de um campo investigativo delimitado pela ideia de longo tempo dos componentes da École dês Annales. (PONTES, 2006).

O bibridismo cultural explica que as culturas não seguem caminhos isolados: elas se encontram, se fecundam, se multiplicam, proliferam; apresenta sempre a ideia de algo resultante do cruzamento de culturas diferentes. Pode ser estudada pelo seu aspecto literário, artístico ou sociocultural. (PONTES, 2006).

https://periodicos.unifap.br/index.php/letras

Macapá, v. 9, n. 1, $1^{0}$ sem., 2019 
O conceito principal é o da residualidade; e se eu tivesse de fazer uma escolha por grau de importância, colocaria este conceito em primeiro lugar; em segundo a cristalização; em terceiro a mentalidade; em quarto o hibridismo cultural. Essas coisas podem ser investigadas tanto separadamente quanto em conjunto, porque uma implica na outra e ajuda a esclarecer ao mesmo tempo o objeto investigado. É o que em teoria chamamos conceitos operativos, ou operacionais, isto é, indispensáveis à operação do esclarecimento (PONTES, 2006).

Dessa forma, podemos dizer, resumidamente, que a Teoria da Residualidade Literária e Cultural busca reconhecer as mentalidades nas várias épocas e estilos, além de procurar justificar a complexidade teórica aplicada por estudiosos acerca da estética literária de autores e obras, bem como ainda explicar a confusa questão que envolve autor, obra e período, ou seja, a periodologia literária.

Diante do exposto, declaramos que é nesse instigante jogo entre religião, tradição, imaginário, mentalidade e residualidade que, mergulhando nos diversos saberes, estruturamos este artigo, buscando nas mais antigas tradições o elo entre o passado e o presente do teatro vicentino - Auto da Barca do Inferno, Auto do Purgatório ou Auto da Praia e Auto da Barca da Glória.

No teatro medieval vicentino, três elementos são importantes para a compreensão da morte como ritual de travessia: o rio, o barco e o barqueiro. Eles estão, visivelmente, presentes na Trilogia das Barcas. São elementos, como veremos logo a seguir, ligados a longa tradição e que, mediante demorado processo de hibridação cultural, transmissão e atualização de substratos mentais, foram se adequando e/ou mesclando-se às formas de pensar a morte na Idade Média, seguindo toda uma concepção religiosa estabelecida pelos ideais do Cristianismo e da Igreja Católica. Sendo assim, primeiramente, vejamos alguns trechos dos autos que compõem a Trilogia das $\operatorname{Barcas}^{8}$ e que ressaltam o tema da morte como travessia:

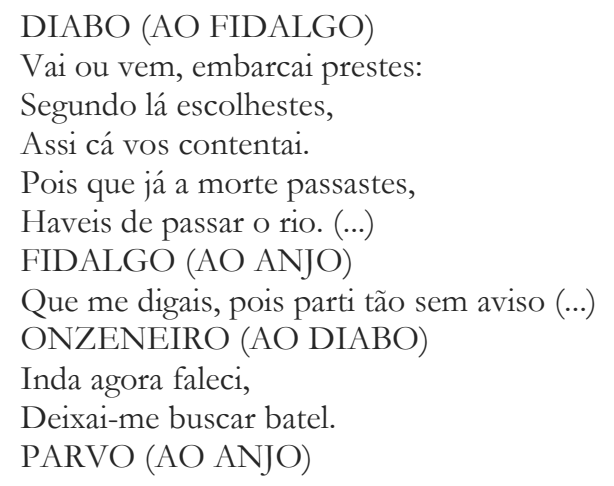

\footnotetext{
8 A partir de agora, todas as citações das obras vicentinas terão como referência o Centro de Estudos Portugueses (C.E.T), da Universidade de Lisboa, Portugal, coordenado pelo Professor José Camões, conforme o site que se segue: Centro de Estudos de Teatro, Teatro de Autores Portugueses do Séc. XVI - Base de dados textual [online]. <http://www.cet-e-quinhentos.com/>[01/06/2017-30/07/2018]. Neste sítio reúne-se as obras que fazem parte da história do teatro em Portugal no século XVI - Teatro de Autores Portugueses do século XVI (ISBN 978 989-95460-5-9), dirigida por José Camões, com Helena Reis Silva, Isabel Pinto, Lurdes Patrício, Inês Morais, Filipa Freitas e José Pedro Sousa; contando ainda com a colaboração de José Javier Rodriguez (textos em castelhano; apresentações), Lucília Chacoto (paremiologia), Manuel Calderón (textos em castelhanos; apresentações), Maria Luísa Oliveira Resende (comédias de Jorge Ferreira de Vasconcelos). Todas as obras de Gil Vicente publicadas no referido site são constantemente atualizadas pela equipe que constitui o C.E.T, supervisionado e coordenado pelo Professor Camões. Conforme o Professor José Augusto Cardoso Bernardes, da Universidade de Coimbra, os estudos desenvolvidos pelo Professor Camões no C.E.T. é referência para os estudiosos do dramaturgo em questão. Portanto, todas citações vicentinas dar-se-ão da seguinte maneira: (VICENTE, C.E.T, Vv). Todos os textos de Gil Vicente são cuidadosamente apresentados e seguem a sua estrutura original de versificação. Os pesquisadores do C.E.T. ainda desenvolvem comentários específicos sobre cada obra vicentina, bem como uma especificação correta das datas de cada texto criado pelo dramaturgo português.
} 
Quereis-me passar além?

OS QUATRO CAVALEIROS

(...) Senhores, que trabalhais / Pola vida transitória,

Memória, por Deus, memória / Deste temeroso cais. (VICENTE, Auto da Barca do Inferno, C.E.T, Vv. 54-826)

\author{
LAVRADOR \\ Da morte venho eu cansado, \\ E cheio de refrigério (...) \\ PASTOR \\ Senão anda que te vás, \\ Enha mãe nega gritar, \\ E chorar que chorarás. \\ Agora quero passar; \\ Perem não me levarás. \\ MOÇA \\ Minha mãe, valei-me aqui \\ Que quando de vós parti, \\ Não cuidei d'achar o Demo. (VICENTE, Auto do Purgatório, C.E.T, Vv. 126-602) \\ MORTE (AO DIABO) \\ (...) Verás como no me escapa \\ Desde el Conde hasta el Papa. \\ Haced prestes la partida. \\ MORTE (AO CONDE) \\ Señor Conde prosperado, \\ Sobre todos mas ufano, \\ Ya passastes por mi vado. \\ IMPERADOR \\ (...) Adonde me traes, Muerte? \\ Que te hice triste yo? \\ CARDEAL \\ Todo hombre que es nacido \\ De muger, tien breve vida; (...) \\ Cuando la vida gozamos, \\ Como dela partimos, \\ Y como sombras passamos (...). (VICENTE, Auto da Barca da Glória, C.E.T, Vv. 36-668)
}

De acordo com a leitura dos fragmentos textuais apresentados, podemos destacar algumas palavras e/ou expressões que nos dão a ideia de travessia, como: "vai ou vem", "passar", "partir", "venho eu cansado", "agora quero passar", "adonde me traes", "breve vida". No contexto, elas designam a transição da vida para o momento da morte. Dessa forma, podemos assim reforçar as concepções de Le Goff, Schmitt, Van Gennep e muitos outros que falaram da morte como um processo de travessia. Acrescentemos ainda a concepção encontrada no Dicionário de Simbolos, de Jean Chevalier e Alain Cheerbrant, em que a morte, "enquanto símbolo [...], além de perecível e destrutível, [...] é introdutora aos mundos desconhecidos do Inferno ou do Paraíso [...]." É um processo em que "todas as iniciações atravessam uma fase da morte". (CHEVALIER; GHEERBRANT, 1991, p. 621). Portanto, a morte, mediante o contexto apresentado, está relacionada a um fenômeno de mudança de estado e/ou movimentação entre universos diferentes - vida e pós-morte; referindo-se também à questão da temporalidade humana, ou seja, à efemeridade da vida. Diz respeito ainda ao processo de mudança - fim e começo de uma nova jornada: um processo que exige do indivíduo um fim, para em seguida, reiniciar uma nova incursão no Alémtúmulo, resultando daí um caminho direto ao Inferno ou ao Paraíso, ou ainda um lugar de espera: o Purgatório. Assim, temos a concepção da morte como espécie de ritual dinâmico 
rumo ao outro lado da vida.

Agora, vejamos a questão da representatividade do rio, do barco e do barqueiro na obra de Gil Vicente. Esses três elementos aparecem, na Trilogia das Barcas, em conjunto, quando os trespassados são encaminhados pela morte para a margem de um rio, ao encontro das barcas, sendo uma do Inferno e a outra, do Paraíso. Há também, implicitamente, uma alusão ao Purgatório - como terceiro lugar do Além.

Ao se defrontarem com as barcas, os mortos avistam os barqueiros: um que representa o Mal, o Diabo, e outro que representa o Bem, o Anjo, preferindo-lhes a sentença:

DIABO

À barca, à barca, ou lá,

Que temos gentil maré.

Ora venha a caro ré:

Feito, feito bem está.

Vai ali muitieramá,

E atesa aquele palanco,

E despeja aquele banco,

Pera a gente que virá.

À barca, à barca, hu!

Asinha, que se quer ir

Oh que tempo de partir?

Louvores a Belzebu.

Ora sus, que fazes tu?

Despeja todo esse leito.

COMPANHEIRO

Em bonora, logo e feito. (...)

DIABO

Oh, que caravela esta!

Põe bandeiras, que é festa;

Verga alta, âncora a pique

Ó precioso Dom Anrique!

Ca vindes vós? Que cousa é esta?

FIDALGO

Esta barca onde vai ora,

Qu'assim está apercebida?

DIABO

Vai para a Ilha perdida,

E há de partir logo essora. (...)

FIDALGO

A est'outra barca me vou.

Ou da barca! Pera onde is?

Ah barqueiros, não me ouvis? (...)

ANJO

Que mandais?

FIDALGO

(...) se a barca do Paraíso

É esta em que navegais.

ANJO

Esta é; que buscais?

FIDALGO

Que me leixeis embarcar:

Sou fidalgo de solar,

É bem que me rocolhais.

ANJO

Não se embarca tirania

Neste batel divinal. (...)

FIDALGO

(...) levai-me desta ribeira. 


\section{DIABO}

Ora muito m'eu espanto

Não vos livrar o dinheiro.

ONZENEIRO

Nem tam soes para o barqueiro,

Não me deixaram nem tanto. (...)

PROCURADOR

Beleguinis ubi sunte,

Ego latinus macairos. (...)

ENFORCADO

Agora não sei que é isso:

Não me falou em ribeira,

Nem barqueiro nem barqueira,

Senão logo ao Paraíso (...).

DIABO

Falou-te no Purgatório? (...). (VICENTE, Auto da Barca do Inferno, C.E.T, Vv. 1-805)

Nesta Barca Primeira, as personagens ao sofrerem o trespasse chegam à beira de um rio, deparam-se com duas barcas e dois barqueiros. As barcas simbolizam espaços antagônicos, ou seja, uma representa o Inferno e a outra o Paraíso. Aqueles que comandam as barcas são, respectivamente, representantes do Mal (Diabo e Companheiro) e, representantes do Bem (o Anjo). A barca infernal tem bandeiras, bancos e um grande espaço, pois assim diz o Anjo ao Fidalgo: "pera vossa fantesia / mui pequena é esta barca", e ainda: "Ireis lá mais espeçoso, / vós e vossa senhoria". À vista do exposto, fica claro que a barca divinal é simples e supostamente pequena, pois poucos a merecem. Essa informação nos aproxima da passagem bíblica de Mateus que destaca os caminhos da perdição e da salvação; uma larga, e a outra, estreita: "Entrai pela porta estreita; porque larga é a porta, e espaçoso o caminho que conduz à perdição, e muitos são os que entram por ela; E porque estreita é a porta, e apertado o caminho que leva à vida, e poucos há que a encontrem. (Mateus, 7: 13-14). Entretanto, na visão do Fidalgo, a barca do Diabo parece um "cortiço". Outro fato que nos chama a atenção é que, entre o leito do rio e a barca, os trespassados têm que passar por uma prancha, como bem ressalta a figura do Fidalgo: "venha essa prancha, e veremos / esta barca tristura. Contudo, a personagem do Enforcado sente-se "enganado", pois não lhe haviam falado "em ribeira / nem barqueiro nem barqueira, / senão logo ao Paraíso". A existência da prancha também nos aproxima da mesma citação bíblica de Mateus, pois pela prancha da Barca da Glória, poucos podem passar. Vale ainda ressaltar que ambos os barqueiros têm o poder de decidir quem vai para o Inferno, para o Paraíso, ou para o Purgatório. Passemos agora aos trechos do Auto do Purgatório, que reforçam o assunto em questão:

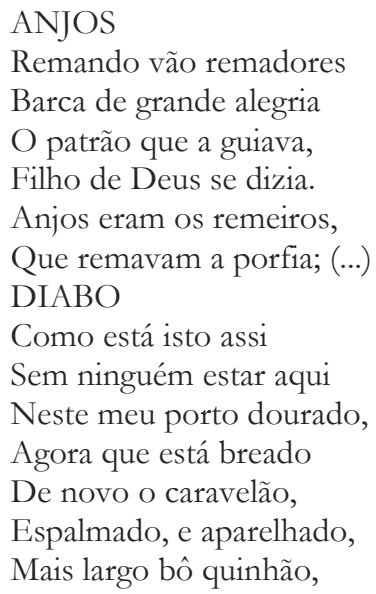


Que o passado? (...)

ANJO

Aviai-vos, e partir; (...)

Este rio é mui escuro,

Não tendes vau nem maneira:

Entrai em barco seguro,

Havei conselho maduro,

Não entreis em má bateira;

Que na viagem primeira,

Quantos vistes embarcados

Todos foram alagados:

No mais fundo da ribeira

São penados.

Pois não se pode escusar

A passada deste rio,

Nem a morte s'estorvar,

Qu'é outro braço de mar

Sem remédio nem desvio (...).

DIABO

(...) Arrenego eu do dinheiro

Que ganho nesta viagem,

Arrenego da barcagem,

E do cornudo barqueiro. (VICENTE, Auto do Purgatório, C.E.T, 1-111)

No Auto do Purgatório mais uma vez nos deparamos com duas barcas: a caravela da Glória, capitaneada por três anjos que carregam seus remos. E a caravela do Inferno, comandada pelo Diabo e seu Companheiro. A Barca da Glória é de "grande alegria", pois "o patrão que a guiava, Filho de Deus se dizia". O enredo do auto se passa numa noite de Natal, por isso, "a ribeira mui serena / que nenhum vento bulia". O Diabo reclama pois seu "porto dourado / agora está breado / de novo o caravelão, / espalmado, e aparelhado, mais largo bô quinhão (...)". O rio, segundo o fragmento, está escuro. Por isso, o Anjo avisa que a Barca da Glória, é a barca segura. Ainda segundo a fala do Anjo, a barca primeira, ou seja, a Barca do Inferno, naufragou e "todos foram alagados". Tudo indica que o fundo da ribeira é o lugar dos danados, o Inferno, pois todos "são penados". Ressaltamos ainda, que a beira do rio é o lugar de purgação, uma vez que muitos personagens permaneceram à margem do rio, purgando seus pecados (Lavrador, Marta Gil, Pastor, Moça Pastora); que poucos adentraram na Barca do Inferno (Taful), assim como poucos também entraram na Barca do Paraíso (Menino). Ainda neste auto vicentino os barqueiros também têm, assim como no primeiro, o poder de decidir o destino dos trespassados. Esses detalhes antes mencionados, também nos lembram o texto bíblico referido linhas antes. Ainda com relação ao Auto do Purgatório, vale dizer que à beira do rio simboliza, de acordo com a leitura do texto, o tempo de espera e a remissão dos pecados de quase todas as personagens que adentram na cena. Passemos agora ao Auto da Barca da Glória e leiamos:

MORTE (AO CONDE)

No fue nada;

La peligrosa passada

Desta muy honda ribera

Es mas flerte e trabajada,

Mas terrible em gran manera.

Ved, señor, si traes flete

Para aquel barco del cielo. (...)

Hablad com ese barquero,

Que yo voy hacer mi officio.

DIABO (AO CONDE) 
(...) entre Vuesa Señoria,

Que bien larga está la plancha (...)

CONDE

Ha mucho que eres barqueiro?

DIABO

Dos mil años há y mas,

Y no passo por dinero.

Entrad, Señor passageiro.

CONDE (AO DIABO)

Voyme á estotra embarcación (...)

ARCEBISPO (AOS ANJOS)

Dadnos alguna esperanza,

Barqueiro del mar del cielo:

Por la llaga de la lanza,

Que nos paseis com bonanza

Á la tierra de Consuelo.

ANJO

És fuerte cosa

Entrar em barca gloriosa. (VICENTE, Auto da Barca da Glória, C.E.T, Vv. 50-610)

Dessa vez, a Morte aparece como personagem e conduz os falecidos no momento do trespasse até a beira do rio. Primeiramente, a Morte os entrega ao Diabo. Em seguida, rejeitando a barca infernal, eles se dirigem à Barca da Glória, pedindo a salvação ao Anjo. Mais uma vez Gil Vicente coloca os seus personagens à margem de um rio. A Barca do Inferno é comandada pelo Diabo e pelo seu Companheiro; já a Barca da Glória tem à frente quatro anjos que trazem consigo cinco remos e cinco chagas. Contudo, apenas um deles tem o poder da palavra, mas todos têm a glória da salvação - os remos e as chagas de Cristo. Neste auto vicentino, não há nenhuma descrição exata das barcas, se grandes ou pequenas, feias ou bonitas, tristes ou alegres. No entanto, ao dirigir-se à barca do anjo, o Conde diz o seguinte: "o muy preciosos remos, / socorred mi afliccion". Assim também diz o Rei: "O remos de gran valor!" Essas referências aos remos podem designar a luminosidade e a beleza celestial da Barca da Glória, fato que também se relaciona com as cincos chagas que os anjos carregavam no início da obra, como bem reforça a fala do Imperador: "...llagas preciosas, / remos del mar mas profundo!". Sendo assim, temos aqui, de modo significativo, a representação do rio, do barco e dos barqueiros como elementos da morte que melhor designam o ritual de travessia.

Porém, de onde vem essa representação da morte como travessia? E o rio? Que simbologia o rio possui no ritual da morte? E o barco, que elemento simbólico e/ou representações ele pode assumir? E o barqueiro, qual a sua função? Pois bem, para tal, é importante retomarmos, em poucas palavras, a história de Portugal do século XV/XVI e ressaltarmos os acontecimentos vivenciados por Gil Vicente, bem como as tradições existentes em seu tempo e a relação do povo português com o mar e as longas viagens.

Segundo João José Alves Dias (1998), Portugal, durante os séculos XV e XVI, viveu momentos de muita complexidade e, ao mesmo tempo, de muita prosperidade e ordenamento. Do final do reinado de D. João II ao fim do reinado de D. João III, época em que se enquadra a vida e nascimento/evolução do teatro vicentino, Portugal viveu a glória de um grande império, descobriu novos mundos e enfrentou uma série de problemas internos e externos ao reino: 1. vivenciou um processo de transição entre uma economia agrária e uma economia comercial, provocado pelas expedições marítimas que uniam a Europa ao Oriente, devidamente apoiadas pela aristocracia e pelo clero da época, fato que conduziu Portugal ao título de grande potência e primeira nação a desbravar os mares em busca de 
riquezas; 2. ao mesmo tempo que crescia e se tornava forte, Portugal também conheceu o tempo de sucessivas guerras, doenças, crescimento da população na zona urbana; 3. enfrentou ainda problemas internos como a expulsãos dos mouros e dos judeus, a conversão dos judeus; 4. tentou manter o sonho de nação imperialista dominadora de um mercado efervescente e manteve a expansão ultramarítima pela África e Ásia. D, Manuel I e D. João III tentaram manter-se firmes nas suas respectivas tarefas de construir uma nação imperiosa. No entanto, o aperfeiçoamento do Estado Novo e a Conquista do Além-Mar, acarretaram trabalho de dedicação e de múltiplos acordos e discordâncias. De acordo com as pesquisas de Dias, “(...) compreende-se que o período exigisse um esforço redobrado de talentos e engenho para ocorrer às muitas necessidades da conjuntura." (DIAS, 1998, p. 65).

Em meio às conquistas e com o título de reino dominante, Portugal, com toda riqueza adquirida pelo comércio de especiarias vindas do Oriente, não chegou a se estruturar e a investir numa modernização do reino, ficando assim, atrasado em relação ao resto da Europa. Como bem afirma Dias (1998), Portugal, durante os séculos XV/XVI, foi um reino forte e, ao mesmo tempo, conturbado, devido às diferenças internas (ideológicas e culturais) existentes na mentalidade do povo lusitano. Entretanto, o mar, as viagens marítimas e suas descobertas trouxeram uma série de transformações para a sociedade portuguesa do século XVI, fato que muito resplandeceu na literatura de quinhentos, bem como na dramaturgia de Gil Vicente. Ainda seguindo os estudos de Dias (1998), nos séculos XV-XVI uma grande quantidade de colonos, soldados, navegantes, missionários, aventureiros e degradados saíram para as grandes viagens marítimas. O êxodo de varões, segundo o autor, "foi muito intenso na primeira metade do século XVI. Visou principalmente a Índia, para onde, até 1527, teriam seguido cerca de 80.000 homens, dos quais só um décimo regressava a Portugal." (DIAS, 1998, p. 20).

O sonho de sair da terra natal rumo ao desconhecido, navegar/fazer travessias por mares dificultosos, vivenciar aventuras marítimas, conquistar lugares distantes, viver e desafiar o mar bravio, deixou marcas residuais na produção de Gil Vicente e contribuiu para o processo de criação da Trilogia das Barcas, uma vez que a navegação representou, por longo tempo, a grandiosidade da alma portuguesa. É importante frisarmos aqui que muitos portugueses sonhavam em viajar nas grandes embarcações e enriquecer rapidamente, mudando assim de vida e conquistando um lugar/posição de nobreza na corte. Porém, para a maioria, isso não passava de um sonho. Muitos homens morreram na miséria. Tal fato foi alvo de duras críticas por parte do autor nos trechos do Auto da india, da Farsa de Inês Pereira e de Nau de Amores?.

Portanto, o barco, o rio e o barqueiro estariam ligados, como bem afirma Dalila Pereira

\footnotetext{
9 O Auto da índia (1509) é um texto que ressalta alguns dissabores da expansão ultra marítima portuguesa: 1. as aventuras do homem português pela rota das especiarias, as grandes descobertas e o sonho de riqueza; 2. A mulher e o adultério; 3. A volta para casa e a (des)ilusão de um sonho que poucos conseguiram concretizar - ficar rico. A Farsa de Inês Pereira, tida como a mais bem trabalhada do autor, é datada de 1523. Nela, o primeiro marido de Inês Pereira, o Escudeiro Brás da Mata, morre em Marrocos na tentativa de tornar-se cavaleiro, deixando viúva sua esposa. Em busca de fama e glória Brás partiu, assim como muitos homens da sua época, à serviço real, desejando tornar-se cavaleiro. Em Nau de Amores (1527), um Príncipe estrangeiro suplica à Cidade de Lisboa uma "Nao", para assim, poder lançar-se às aventuras marítimas em busca da Fama. Ele encontra-se apaixonado e sua "Nao" deverá ser construída com elementos que representem os prazeres e as dores do amor: "voluntad de madera / y la razon plega dura, / dorada toda de fuera (...) / la vela de esperanza, / la gávea de hermosura, / el traquete de membranza (...)". (VICENTE, Nau de Amores, CET, Vv. 367-510). O Príncipe ressalta a grandiosidade do povo português porque neste reino havia "nao que descobrió / tantas ínsulas inotas, / quantos reinos Dios crió / y desbarato mil flotas." (VICENTE, Nau de Amores, CET, Vv. 367-510).
} 
da Costa, a uma "geografia transcendente" marcada pela realidade da água - Rio Tejo e o além-mar -, o homem e a morte. Sobre o assunto, Dalila Pereira da Costa afirma:

Morte, como danação ou salvação eterna, justamente então decidida nessa passagem pela água, será o fulcral das Barcas. Mas nelas havendo esse cenário de geografia transcendente, aqui marcada pela realidade da água, como a miticamente eleita por uma muito antiga comunidade de povos atlânticos: "passada deste rio", "braço de mar", "ilha perdida": todas estas localizações demonstrarão, nestas três obras, a persistência duma certa tipologia de conhecimento secreto escatológico, pertença dos arcanos portugueses: e ao qual Gil Vicente, pela sua funda e intrínseca ligação à alma portuguesa, teve acesso. (COSTA, 1989, p. 165)

Conforme Eugênio Asensio (1974), desde Teófilo Braga muitos pesquisadores tentam relacionar o conteúdo das Barcas com as navegações e a cultura portuguesa. Na concepção do pesquisador, há fortes indícios na Trilogia das Barcas referentes ao caráter marítimo do povo português, como acontece, por exemplo, no Auto da Barca do Inferno, onde o Fidalgo diz:

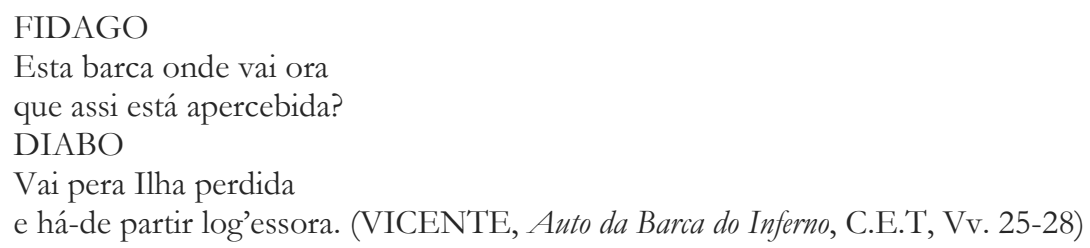

A "Ilha perdida", de acordo com a leitura do texto, faz referências aos territórios, ilhas, ilhotas e povos encontrados pelos portugueses durante o Processo de Expansão Ultramarina, bem como ainda às ilhas onde muitos navegadores, diante dos desastres de navios e/ou desvio de rotas, permaneciam até à morte; sumiam e/ou se perdiam no mar.

Outra referência, segundo os apontamentos de Eugênio Asensio (1974), é uma breve alusão às grandes viagens marítimas e aos descobrimentos que aparece na fala de Marta Gil, no Auto da Barca do Purgatório, quando a personagem diz: "ora assi me salue Deos/ e me livre do Brasil". (VICENTE, Auto da Barca do Purgatório, C.E.T, Vv 299-300). Ainda conforme Eugênio Asensio podemos encontrar, nas Barcas vicentinas, referências/alusões à obra de Dom Duarte, o Leal Conselheiro: "la barca de estado dos pecados y la del estado das virtudes” (ASENSIO, 1974, p. 70). De acordo com a obra de Dom Duarte, após o chamado de Deus, os trespassados se deparam com um rio, com duas barcas e seus representantes, estando assim, à margem de dois destinos. A primeira barca, como podemos ver no texto a seguir, é velha, fraca, podre. Quase todos se perdem, e poucos se salvam. Já a segunda é forte, segura e muito bem aparelhada; nela, raramente alguém se perde. Uma, supostamente vai para o Céu; a outra para o Inferno. Vamos então ao Leal Conselheiro (1942) ${ }^{10}$, de Dom Duarte:

Ainda que Deos por sua grande, ab ssoluta, infi(inda) e segreda vontade alguas vezes scolha e chame alguus de stados vyciosos e culpados, assy como escolheo sam Matheu do Stado pecador dos publicanos husureiros, e Maria Magdanella do stado pecador das molheres, e o ladrom do stado dos malfeitores e

\footnotetext{
${ }^{10}$ De acordo com o prefácio de Joseph M. Piel (1942), o Leal Conselheiro foi uma obra elaborada pelo filho primogênito de D. João I, Dom Duarte, a pedido da sua mulher Dona Leonor. Nesta obra, Dom Duarte reuniu num só volume a maior parte dos seus escritos e apontamentos diversos de boa conduta, moral e religiosidade, ou seja, "um abc de lealdade". Possivelmente, foi redigido em 1435, contudo, há muitas divergências e imprecisões a este respeito. (DOM DUARTE. Leal Conselheiro. Edição crítica, anotada e organizada por Joshep M. Piel e preparada pela Faculdade de Letras de Coimbra, sob o patrocínio do Instituto para a Alta Cultura. Lisboa: Livraria Bertrand, 1942).
} 
danadores, e assy permita danar e perder outros de stados perfeitos e virtuosos, assy como Judas do estado dos apostollos, e Nycolaao do stado dos dicipullos, por isso tam grande sandice he em atrevimento da boa vontade de Deos desprezar o estado das virtudes, e escolher o estado dos pecados, como seria se alguu quisesse passar alguu ryo perigoso e tormentoso, e achasse duas barcas: hua forte e segura e muy bem aparelhada, e em que raramente alguu se perde e por a mayor parte todos em ella se salvam, e otra velha, fraca, podre, rota, em que todos se perdem, e alguus poucos se salvam. A barca firme e segura e forte e bem aparelhada, o estado das virtudes he, e de boo santo vyver honesto, e sem querela de Deos e do prouxymo, em que muy poucos perecem e a mayor parte se salva, em tal estado assy como (em a) barca segura podem navegar seguramente e passar sem perigoo per as ondas da tormenta deste mundo a porto seguro e (divinal) prazer que he a gloria. A barca fraca, podre, rota, o estado dos pecados he, e da maa e corrupta e des(s)oluta vyda, em tal estado assy como em barca podre nom pode com segurança e sem perigoo as tormentas da presente vyda passar, nem a porto de folgança e desejado porto aportar. E que alguus se salvem, isto he de veentuira, ou por alguu segredo juyzo de Deos acerca dalgua syngullar pessoa, que nom quer que seja a myutos conssequencia, por que pryvylegio de poucos nom he subsidio e defesa aos muytos, y salva muy poucos. Outro enssynamento; cousa perigosa he scolher homem estar no lugar onde morrem de pestellença, e cousa mais segura partisse, ca mais morrem dos que ficam, e poucos dos que partem. (DOM DUARTE, 1942, p. 350-351)

As Barcas de Dom Duarte, como podemos perceber, estão ligadas às virtudes e aos pecados mundanos do homem. Diante da Vontade de Deus, os trespassados, mediante o modo de vida, são levados a entrar numa barca velha, podre e insegura, "em que todos se perdem", ou adentrar numa barca segura e muito bem aparelhada, "em que raramente alguu se perde e por a mayor parte todos em ella se salvam"; ou seja, uma barca segura na qual todos pudessem navegar e passar com segurança pelas ondas tormentosas "deste mundo a porto seguro". Tais barcas logo nos aproximam das Barcas vicentinas, uma do Inferno e, a outra, do Paraíso. Retomando alguns trechos do Auto do Purgatório, a Barca da Glória é de "grande alegria... o patrão que a guiava, Filho de Deus se dizia"; já a Barca do Inferno, naufragou e "todos foram alagados", pois era velha e fraca; parecia um cortiço. (VICENTE, Auto do Purgatório, C.E.T, Vv. 2-63). No referido texto de Dom Duarte, também encontramos referências ao rio - "rio perigoso e tormentoso"; e ao barqueiro - de estados perfeitos e virtuosos e de estados malfeitores. Destarte, nas Barcas de Gil Vicente, há, como podemos observar na leitura do texto de Dom Duarte, resíduos temáticos da forma de pensar a morte (que chega para os que são bons/virtuosos e para os que são maus/pecaminosos), a travessia (a passagem do plano terreno para o espiritual por meio da Morte), o barco (do Bem, glorificada, forte e que vai para o Céu; a do Mal, fraca, velha e que vai para o Inferno), o rio (perigoso; supostamente, o lugar dos pecadores) e o barqueiro (o Anjo e o Diabo: os sentenciadores).

Em face do evidenciado, a tradição acerca da morte como algo referente à travessia e o rio, o barco, o barqueiro, como elementos simbólicos dessa travessia, não pertencem somente a Idade Média e à sua forma de pensar. Ela também se manifestou nos de tempos remotos, como bem demonstram a literatura e a cultura do povo da Mesopotâmia, do Egito Antigo e da Grécia Antiga. Da civilização Mesopotâmica, citemos um trecho da Epopeia de Gilgamesh que narra a travessia do herói pelo mundo dos mortos:

Gilgamesh, como vais atravessar o Oceano? Quando chegares às águas da morte, o que farás? Mas, Gilgamesh, no meio da floresta encontrarás Urshanabi, o barqueiro de Utnapishtim; com ele estão os objetos sagrados, os objetos de pedra. Ele está talhando a proa do barco em forma de serpente. Observao bem. Se for possível, talvez consigas atravessar as águas do Oceano com ele; se não, terás de voltar. (...)

(...) Sou Urshanabi, o barqueiro de Utnapishtim, o Lomgíquo. (...)

Gilgamesh: (...) Urshanabi, mostre-me o caminho para chegar até Utnapishtim. Se for possível, atravessarei as águas da morte, se não for, vagarei por regiões ainda mais desoladas.

(...) Eles então subiram no barco, Gilgamesh e Urshanabi, e o lançaram sobre as ondas do Oceano.

https://periodicos.unifap.br/index.php/letras

Macapá, v. 9, n. 1, $1^{0}$ sem., 2019 
Durante três dias eles singraram o mar com velocidade, percorrendo o equivalente a uma jornada de um mês e quinze dias. Urshanabi por fim levou o barco às águas da morte. Ele então disse para Gilgamesh: vai em frente, pega uma das toras e empurra-a para dentro do mar, mas não encostes tua mão na água. (...)

(...) Assim Urshanabi, o barqueiro, trouxe Gilgamesh até Utnapishtim, a quem chamam o Longínquo e que vive em Dilmun, a leste da Montanha, no lugar por onde transita o sol. Sobre a ele, entre todos os homens, os deuses concederam vida eterna.

(...) Foi para ver Utnapishtim, a quem chamamos Longínquo, que fiz esta jornada. Por isso vagueei pelo mundo, atravessei tantas cordilheiras perigosas, cruzei os mares e me esfalfei viajando. (...) (ANÔNIMO, Gilgamesh, 2011, p. 150-155)

Diante dos fragmentos citados, podemos observar a importância do barqueiro e do barco no processo de travessia pelas águas da morte. A barca, assim como o barqueiro, são símbolos de segurança e de salvação, desde que a travessia é perigosa e eternamente mortal. Entretanto, nenhuma outra civilização dentre os povos da Antiguidade Clássica teve tanto interesse pelos mistérios da morte quanto os egípcios. Eles ficavam perturbados pelos enigmas da morte. Dessa forma, os antigos egípcios além de desenvolverem uma tradição ritualística "esotérica e imemorial" acerca da morte, ainda criaram O Livro dos Mortos.

Segundo o Livro dos Mortos, os trespassados, depois do "susto da morte", teriam que fazer uma travessia pela "região das trevas" para, logo depois, chegar ao Amenti, onde seriam julgados na presença de Osíris, deus egípcio. De modo quase semelhante com o Livro dos Mortos, nas Barcas vicentinas, os mortos chegam à beira do rio por meio da morte, que direta ou indiretamente, aparece em cena. Ao chegarem às margens do rio, se deparam com duas barcas e dois barqueiros, ambos, respectivamente, representando o Bem e o Mal. Todos passam por uma prancha para adentrar às respectivas barcas. Ainda às margens da ribeira, os trespassados serão julgados e seguirão viagem para o Inferno, tendo punição eterna, ou para o Purgatório, para purgar os pecados mundanais, ou para o Céu, obtendo assim, a salvação. É o que podemos observar na seguinte citação do trecho do Auto da Barca da Glória, por exemplo:

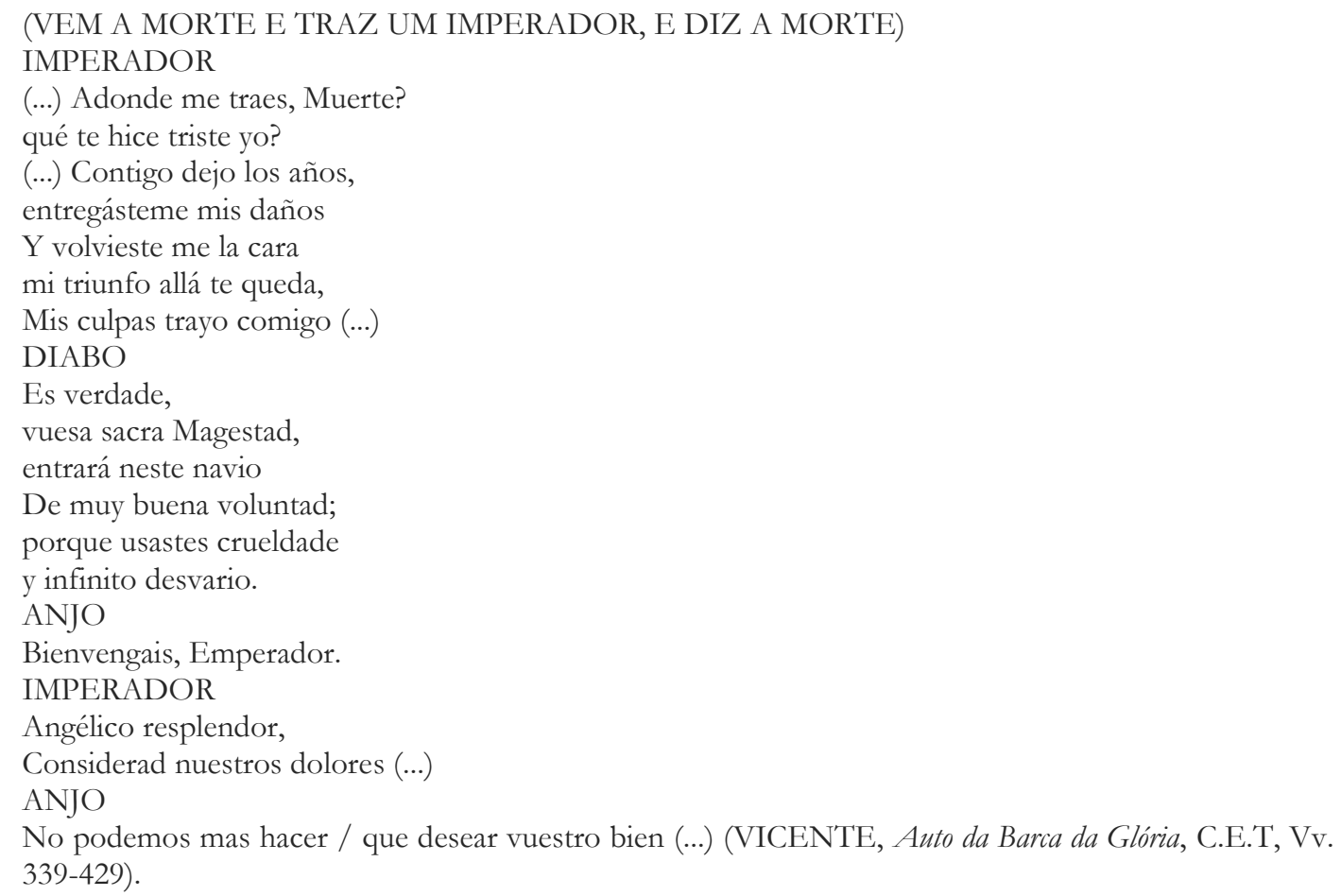


A Barca de Rá, citada várias vezes no Livro dos Mortos, era a que conduzia o deus $\mathrm{Ra}$ através do espaço, durante o dia e a noite. Os defuntos deveriam ter em mente os ensinos e as orações contidas no Livro dos Mortos, que serviriam como guia, tanto para fazer a travessia como para subir na Barca Celeste. Vale a pena destacar que a Barca, de acordo com Brancaglion (1994/1995), era símbolo de proteção e salvação. Para termos uma noção melhor sobre a importância da Barca, da Travessia e da segurança que os mortos tinham ao invocar a Barca de Rá, vejamos o capítulo CII: "Para subir na Barca de Ra":

\footnotetext{
Salve, oh! Grande divindade, que navegas em tua Barca! Transpondo até aqui, diante de ti, compareço. Deixa-me subir à ponte de comando e dirigir a manobra da Barca, como fazem teus servidores, os Arcontes dos Planetas...(Não! Não! Não! Essas imundices eu não como! Só tocá-las com minhas mãos ou pisá-las com minhas sandálias, me causa asco e horror!). Pois as oferendas sepulcrais não me faltam: meus pães são feitos de trigo branco; minha bebida extraída do trigo vermelho! Ah! Os barcos trazem minhas oferendas, ei-las aquil E estas oferendas são colocadas sobre o altar de Heliópolis. Glória ao Olho divino, o que percorre o Céu! Se os Espíritos-Cães me atacarem, eu saberei defender-me! Eis que avanço e tiro esse deus das mãos dos meus inimigos que causam dano ao seu dorso, a seus braços e a suas pernas. Eu circulo na Barca de Ra e os desígnios deste deus são minha única lei. (ANÔNIMO, Livro dos Mortos, 2005, p. 116-117)
}

Para ser admitido na Barca, o morto deveria ter cumprido todas as purificações rituais. É importante salientarmos também que o barqueiro, condutor da barca, tinha poder de juiz, portanto, ele julgava ser prudente ou não a entrada do defunto na Barca de Ra. Pois bem, se a Barca de Rá era considerada a da segurança, então, ela se assemelha à Barca da Glória, de Gil Vicente, pois poucos mereceram adentrá-la e embarcar com segurança rumo ao Além-túmulo. Além disso, ainda em Gil Vicente tanto o Anjo quanto o Diabo tinham o direito de decidir o destino dos trespassados. É o que podemos perceber na seguinte fala do Anjo no Auto do Purgatório:

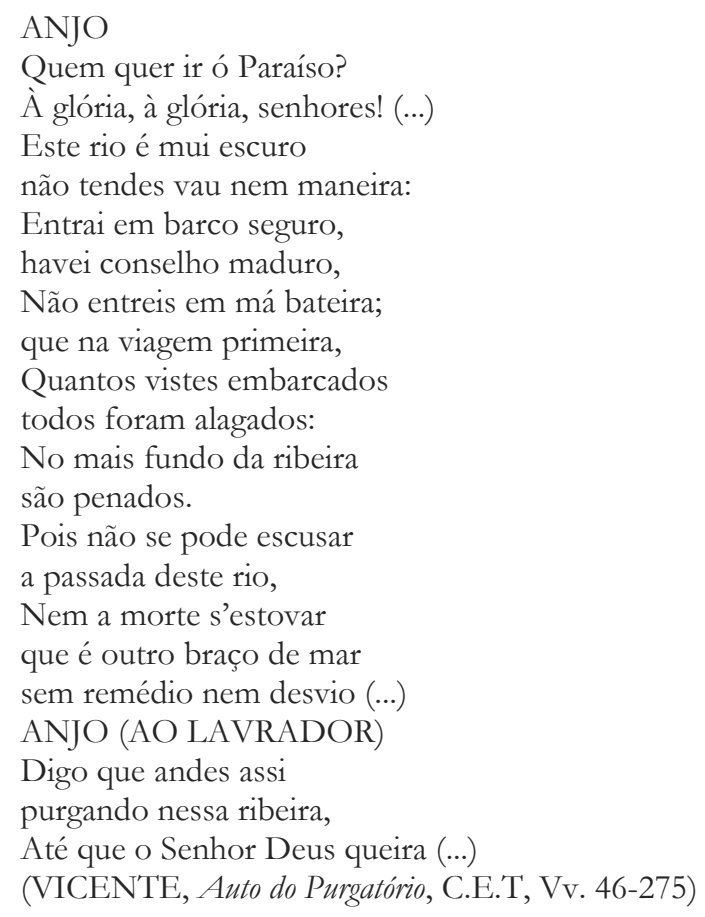

Estamos diante de uma tradição que não só aparece no Livros dos Mortos, mas também, que se torna presente em outra época, como a Medieval, e em obras de intenso valor cultural 
e religioso, como as de Gil Vicente.

Para os gregos, a morte também tinha um significado importante. Ainda segundo Mircea Eliade (2010), ela não trazia a extinção total e definitiva do homem, mas era humilhante, complexa e gerava sentimentos incertos. Era decidida no instante do nascimento humano e, durante a vida, "era simbolizada pelo fio tecido pela Moira dos deuses" (ELIADE, 2010, p. 249). Tudo na vida do homem estava traçado pelo destino. Contudo, aqui, não iremos recorrer à epopeia clássica para mostrarmos a questão da travessia, do barco, do rio e do barqueiro, mas sim, à comédia grega, em especial, As Rãs, de Aristófanes.

Neste texto de Aristófanes, Dioniso, deus da vinha e do teatro, junto de seu criado e amigo Xantias, desce às terras infernais para resgatar a essência do teatro grego, pois com a morte de Ésquilo, Sófocles e Eurípedes, o teatro havia entrado em profunda decadência. Em As Rãs, Aristófanes descreve a aventura do deus Dioníso pelo mundo dos mortos: o encontro com o irmão Hércules, pois este já havia feito a travessia ao Hades; a travessia pelo rio dos mortos, sendo este conduzido pelo barqueiro Caronte; o encontro com os iniciados e o coro das rãs (momento de intenso lirismo poético); o encontro com Cérbero e outras entidades guardiãs das portas infernais; o diálogo com Áiaco, um dos juízes do inferno, e com Hades, o deus do mundo dos mortos; o peso da tragédia de Ésquilo e da tragédia de Eurípedes e a sentença final. Leiamos então apenas trechos referentes à travessia, ao rio dos mortos, ao barco e ao barqueiro:

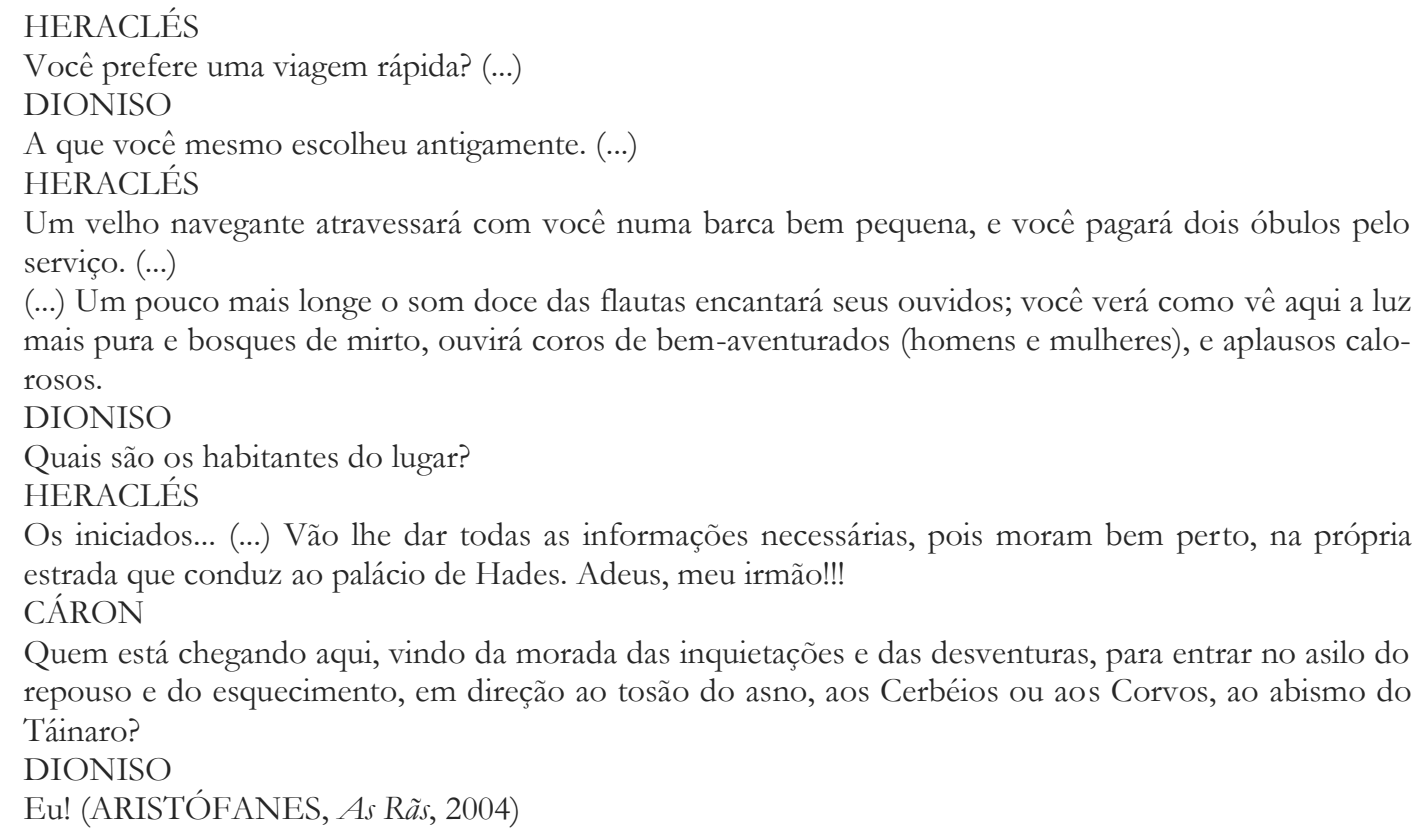

No trecho, Hereclés ou Hércules, irmão de Dioniso, descreve todo o caminho que o deus do teatro deverá seguir para chegar às terras Infernais. Trata-se de um ato ritualístico sagrado, uma vez que a descida ao Hades é perigosa e atormentadora. Segundo a obra, Dioniso deverá atravessar um rio "numa barca bem pequena" e pagar dois óbulos ao barqueiro pelo serviço prestado. É importante ressaltarmos aqui a importância do barqueiro Caronte, do óbulo e a sua proteção rumo ao mundo dos mortos. São elementos culturais da morte e do Além-mundo que, como mostramos anteriormente, também se fez presente na cultura egípcia e que, de modo natural, mediante ao processo de bibridação cultural adentrou a mentalidade cristã durante o medievo, cristalizando-se na alegoria do Diabo, fazendo-se 
presente, em especial, nas obras vicentinas.

Nas barcas de Gil Vicente, além das referências às barcas do Paraíso e do Inferno, há referências ao barqueiro e ao pagamento do óbulo. No Auto da Barca do Inferno, por exemplo, diz o Onzeneiro: "nem tam soes pera o barqueiro, / não me deixaram nem tanto”. (VICENTE, C.E.T, Vv. 192-193). Já no Auto da Barca do Purgatório, o Diabo diz o seguinte: "Arrenego eu do dinheiro / que ganho nesta viagem, / arrenego da barcagem, / e do cornudo barqueiro" (VICENTE, C.E.T, Vv. 109-111). Segundo Andrés José Pociña Lopes (2006), muitos pesquisadores apontam uma possível influência do arquétipo de Caronte nas Barcas de Gil Vicente. Na concepção dos mesmos, conforme aponta o autor, algumas práticas pagãs sobreviveram na tradição portuguesa, dentre as quais, a prática do óbulo, deixando assim, evidências marcantes na obra vicentina. Outros pesquisadores, como Teófilo Braga (1898), acreditavam que as Barcas fossem uma adaptação da tradição pagã:

$\mathrm{O}$ Auto da Barca do Inferno é uma allegoria do paganismo, que Gil Vicente pela sua audácia adapta à crença catholica; as barcas transportando os mortos para serem julgados acham-se referidas em uma lenda céltica conservada por Procópio. "elle conta que as almas que morreram nas Gallias são transportadas cada noite para as margens da ilha da Bretanha, e entregue as potencias infernaes pelos barqueiros da Frísia ou da Batávia. Estes barqueiros não vêem ninguém, mas por alta noite uma voz terrível os chama ao seu mysterios officio" (sic)...(BRAGA, 1898, p. 310)

Assim, podemos afirmar que há resíduos do arquétipo de Caronte nas Barcas do autor português, pois a própria fala do Diabo no Auto da Barca do Purgatório, citada anteriormente, confirma tal visão. E, para reforçarmos esta nossa concepção sobre o assunto, vejamos, em poucas linhas, Luciano no Diálogo dos Mortos. Esta obra, de cunho cômico, satírico, paródico, destaca também a questão da morte, bem como o processo da travessia para chegar ao Hades. Nela, nos deparamos também com o rio dos mortos, com o barco e o barqueiro e a questão do óbulo como pagamento pela travessia, que seria algo obrigatório. Caronte conduz os trespassados, todos na forma de esqueletos, pelo vale dos mortos. Trata-se de uma travessia, assim como vimos nas falas de Héracles, em As Rãs, perigosa e conturbada. Luciano, por meio dos diálogos estabelecidos entre os defuntos diz que, diante da morte, todos são iguais, pois caminham para o mesmo destino: o Além-túmulo. Leiamos:

\section{DIÓGENES}

Mas, ó belo Mausolo, tu não possuis mais essa força nem essa beleza! Pelo menos, se escolhermos um juiz para julgar a beleza, não posso dizer por que razão o teu crânio merece mais honras do que o meu, porque ambos estão calvos e nus! E ambos achatado. (...)

CARONTE

Ouvi qual é a vossa situação. O barco é pequeno, como vós vedes, está comido por bicho, recebe água por muitos pontos e se oscilar para um bordo e para outro afundará de casco para o ar. Por outro lado, vocês chegam em tão grande número, ao mesmo tempo, cada um transportando grande carga. Ora, se vocês embarcarem com tudo isso, receio que depois vos arrependais, sobretudo, os que não sabem nadar. (...)

CARONTE (FALANDO COM HERMES)

E tu, ó Hermes, trate, a partir de agora, de que nenhum deles que não venha em pelo seja recebido, depois de jogar fora, como eu já disse, a bagagem. De pé firme, junto à escada, passe-os em revista, receba-os, forçando-os a subirem nus. (...)

CARONTE

Paga, ó maldito, a passagen!

MENIPO

Grita, ó Caronte, se isso te dá mais prazer!

CARONTE

Paga - eu digo - o dinheiro por que eu te transportei! 
MENIPO

Não poderás recebê-lo de quem não o tem.

CARONTE

Há alguém mais que não tenha um óbulo? (...). (LUCIANO, Diálogo dos Mortos, 1998)

Os trespassados, na obra de Luciano, são obrigados a fazer a travessia num barco "pequeno", "comido por bicho", que "recebe água por muitos pontos" e, se oscilar para um dos lados, poderá afundar. Tal embarcação conduzida pelo barqueiro Caronte e seu ajudante, Quíron, nos lembra a Barca Primeira de Gil Vicente, na qual, segundo as falas do Anjo, no Auto da Barca do Purgatório, na primeira viagem "todos foram alagados I no mais fundo da ribeira (...). (VICENTE, Auto do Purgatório, C.E.T, Vv. 63-64). Já o Fidalgo, no Auto da Barca do Inferno, assim diz, referindo-se à barca do Diabo: "Parece-me isso cortiço". (VICENTE, Auto da Barca do Inferno, C.E.T, v. 31). No que se refere ao óbulo, no Auto da Barca da Glória, encontramos uma fala do Diabo ao Conde que diz: "no passo por dinero. Entrad, señor passageiro". (VICENTE, Auto da Barca da Glória, C.E.T, Vv. 7980). Na obra de Luciano, o pagamento do óbulo era necessário como bem podemos observar na seguinte fala de Caronte a Menipo: "Paga, ó maldito, a passagem! (...) Paga - eu digo - o dinheiro por que eu te transportei".

Por fim, podemos afirmar haver elementos residuais vivos da tradição clássica na dramaturgia vicentina no referente ao barqueiro Caronte e à tradição do pagamento do óbolo para a travessia dos mortos. E ainda podemos observar, diante de todo o exposto, que a morte como travessia, o barco, o rio e o barqueiro, símbolos de segurança e salvação, quase sempre foram elementos simbólicos presentes, de acordo com a mentalidade de cada época, na vida do homem, atualizando-se, como vimos anteriormente, na obra de Suassuna; resíduos latentes oriundos das mais antigas sociedades que se difundiram na formação do pensamento Ocidental ao longo do tempo. Assim, seus conceitos, realizações, representações e valores simbólicos/alegóricos são, de fato, elementos que nos conduzem a uma série de questionamentos e inquietações. A representação desses elementos na Mesopotâmia, no Egito e na Grécia nos fascina. Seja nas epopeias ou nas comédias, ganha, independentemente do tempo e do espaço, notoriedade e valor coletivo nas sociedades ocidentais, permanecendo, de forma atualizada, como resíduos dos ritos de passagem, que tanto se fizeram reviver na sociedade cristã medieval, como vimos nas obras de Gil Vicente - Auto da Barca do Inferno, Auto do Purgatório e Auto da Barca da Glória -, representados e encenados com maestria para toda a corte portuguesa do século XVI, pois, como bem afirma Roberto Pontes, "na cultura e na literatura nada é original, tudo é resíduo em sua origem." (PONTES, 2006, p. 02).

\section{Referências}

ANÔNIMO, Gilgamesh. Tradução realizada a partir da versão inglesa estabelecida por N.K. Sandars por Carlos Daudt de Oliveira. 3 ed. São Paulo: Editora WMF Martins Fontes, 2011. ANÔNIMO. Livro dos Mortos. Trad.: Edith de Carvalho Negraes. 9 edição. 18 reimpressão. Hemus:São Paulo, 2005.

ARISTÓFANES. As Rãs. Tradução do grego e apresentação de Mário da Gama Kury. 3 ed. Rio de Janeiro: Jorge Zahar Editora, 2004.

ARIÈS, Philippe. O Homem diante da morte. Vol. I. Trad.: Luiza Ribeiro. Rio de Janeiro: F. Alves, 1989.

ASENSIO, Eugênio. "Las fuentes de las Barcas de Gil Vicente. Lógica intelectual e 
imaginación dramática”. In: Estudos Portugueses. Paris: Fundação Calouste Gulbenkian/Centro Cultural Português, 1974, pp. 59-78.

BRAGA, Teófilo. Gil Vicente e as Origens do Theatro Nacional. Porto: Livraria Chardron Casa Editora, 1898.

BRANCAGLION JR, Antônio. "O eufemismo da morte no Antigo Egito”. Clássica. Revista Brasileira de Estudos Clássicos. Vol. 7/8. São Paulo:FAPESP, 1994/1995.

COSTA, Dalila Pereira da. Gil Vicente e sua época. Lisboa: Guimarães Editores, 1989.

DIAS, João José Alves. Nova História de Portugal - Portugal do Renascimento à Crise Dinástica. Vol. V. Direção de Joel Serrão e A. H. de Oliveira Marques. Coordenação: João José Alves Dias. Lisboa: Editorial Presença, 1998.

DOM DUARTE. Leal Conselheiro. Edição crítica, anotada e organizada por Joseph M. Piel e preparada pela Faculdade de Letras de Coimbra, sob o patrocínio do Instituto para a Alta Cultura. Lisboa: Livraria Bertrand, 1942.

ELIADE, Mircea. História das Crenças e das Ideias Religiosas. Vol. I. Trad.: Roberto Cortes de Lacerda. Rio de Janeiro: Jorge Zahar Editora, 2010.

LIMA, Francisco Wellington Rodrigues. A Representação da Morte, do Julgamento e da Salvação no Teatro Medieval Português de Gil Vicente e Seus Aspectos Residuais no Teatro Contemporâneo Brasileiro de Ariano Suassuna. Tese de Doutorado, Universidade Federal do Ceará, Centro de Humanidades, Programa de Pós-Graduação em Letras, Fortaleza, Ceará, 2018.

LUCIANO. Diálogo dos Mortos. Introdução, versão do grego e notas de Américo da Costa Ramalho. Brasília: Editora Universidade de Brasília, 1998.

PONTES, Roberto. Literatura insubmissa afrobrasilusa, Rio de Janeiro/Fortaleza, Oficina do Autor, EDUFC, 1999.

. MARTINS. Elizabeth Dias. Residualidade ao Alcance de Todos. Fortaleza: Expressão Gráfica e Editora, 2015.

. Entrevista sobre a Teoria da Residualidade, com Roberto Pontes, concedida à Rubenita Moreira, em 05/06/06. Fortaleza: (mimeografado), 2006.

VICENTE, Gil. Obras Completas. Centro de Estudos de Teatro, Teatro de Autores Portugueses do Séc. XVI - Base de dados textual [on-line]. <http://www.cet-e-quinhentos.com/> [01/06/2017 a 01/07/2018]. 